Fall 1992

\title{
Authoring the Educated Self: Educational Autobiography and Resistance
}

Susan D. Franzosa

Fairfield University, sfranzosa@fairfield.edu

Follow this and additional works at: https://digitalcommons.fairfield.edu/education-facultypubs Copyright Wiley-Blackwell 1992.

This is the author's pre-print version of an article submitted for publication and subsequently published in Educational Theory. The definitive version is available at www3.interscience.wiley.com. DOI: 10.1111/j.1741-5446.1992.00395.x

\section{Repository Citation}

Franzosa, Susan D., "Authoring the Educated Self: Educational Autobiography and Resistance" (1992). GSEAP Faculty Publications. 4.

https://digitalcommons.fairfield.edu/education-facultypubs/4

\section{Published Citation}

Franzosa, Susan Douglas. "Authoring the Educated Self: Educational Autobiography and Resistance," Educational Theory, 42(4) Fall 1992, 395-412.

This item has been accepted for inclusion in DigitalCommons@Fairfield by an authorized administrator of DigitalCommons@Fairfield. It is brought to you by DigitalCommons@Fairfield with permission from the rightsholder(s) and is protected by copyright and/or related rights. You are free to use this item in any way that is permitted by the copyright and related rights legislation that applies to your use. For other uses, you need to obtain permission from the rights-holder(s) directly, unless additional rights are indicated by a Creative Commons license in the record and/or on the work itself. For more information, please contact digitalcommons@fairfield.edu. 


\title{
AUTHORING THE EDUCATED SELF: \\ EDUCATIONAL AUTOBIOGRAPHY AND RESISTANCE
}

\author{
SUSAN DOUGLAS FRANZOSA
}

\begin{abstract}
I don't know how far I differ from other people. That is another memoir writer's difficulty. Yet to describe oneself truly one must have some standard of comparison, was I clever, stupid, good looking, ugly, passionate, cold? Owing partly to the fact that I was never at school, never competed in any way with children of my own age, I have never been able to compare my gifts and defects with other people's. ${ }^{1}$ Virginia Woolf
\end{abstract}

In this essay I explore the themes of accommodation and resistance as they emerge in stories autobiographers tell about their early schooling. My concern is to illustrate how educational autobiographies can add to an understanding of the process of normalization that children experience in school. Many forms of expression can rightly be called autobiographical and all written autobiographies are in some sense educational. ${ }^{2}$ My discussion here, however, draws only on written texts intended for publication as autobiographies that have recounted their authors' formal educational experiences.

As Virginia Woolf understood, schooling can play a crucial role in regulating personal identity. It can teach children how they differ from others and whether these differences will be understood as gifts or defects within a larger social context. Woolf felt that part of her own inability to write an autobiography stemmed from being unschooled. She regretted the absence in her childhood of lessons in "a standard of comparison" that would allow her to place herself among others. What Woolf seems to have yearned for was an irrevocably lost connection to children of her own age. She seems to have been unaware of the potentially oppressive nature of institutionalized standards and comparisons that would have placed and defined her at school.

Unlike Woolf, schooled children who grew up to write published autobiographical accounts of their formal educational experiences have seen the problems of self-representation differently. Schooling has not been understood as making it easier to "describe oneself truly." In fact, school experience is more often portrayed in autobiographies as a source of self-alienation which has to be countered and overcome in order to find an authentic voice. Adults who look back to rewrite their school stories attempt implicitly (but more often explicitly) to contest the school's power of characterization and reclaim the authority to create their own identities. Their educational autobiographies represent an effort to displace the school to become the "true" author of an educated self.

Writing one's own story constitutes an attempt to break with and resist conventional assumptions about who an autobiographer is and what his or her experiences have meant. Becoming the author of one's self, claiming the authority to tell the "true story" of one's "real self," thus involves an appraisal of the social and historical context in which the story is set. As Carolyn Steedman maintains, in the process of determining what features of that context have significance and describing their connections and influences, autobiographers necessarily engage in a form of critique. An autobiography "becomes a piece of history, an interpretative device." 3 
One tells her or his "side of the story" in autobiography by bringing together an understanding of personal identity and cultural context that are meant to call into question a taken-for-granted rendition and logic of a time and place.

In what follows, I briefly examine the conceptual components of normalization, outline the discursive problems of autobiography as a genre, and offer an analysis of the narrative framing of early school experience in educational autobiographies. While the narratives involving late adolescence and adulthood are also important to an understanding of educational experience, my references will be confined to stories autobiographers tell about being young children at school.

I concentrate on the period Richard Coe has distinguished as "the childhood" within autobiography, for two reasons. ${ }^{4}$ First, imaginatively looking at schooling through the eyes of a child commits an autobiographer to apprehend it as a new problem to be solved. Second, in my reading of autobiographies - which have been written from significantly different times and places as well as from the particularities of their author's culture, gender, race, and class - I have been struck by commonalities in the way autobiographers, despite their differences, depict their early childhood realizations of the power of schools. The presence of these commonalities in such diverse texts, it seems to me, can tell us something important about how relations of power operate within schools and add to our understanding of the strategies individuals use to come to terms with their institutional normalization.

\section{NORMALIZATION, ACCOMODATION, AND RESISTANCE}

"What are you?" someone would ask as four or five us walked up Oxford St. to St. Luke's School on Summit Ave. What are you? And each little girl answered promptly, with satisfaction, as if counting up their family silver: "I'm Norwegian," "I'm German," or the most frequent reply, "I'm Irish." Occasionally there was a rebel who said, defensively, obviously coached at home, "I'm American." But this was frowned upon and considered an affectation. "I mean what are you really?"5 Virginia Hampl

The growth of public systems of education in Europe and North America during the $19^{\text {th }}$ century coincided with the broad social and economic changes that accompanied the Industrial Revolution. There was widespread anxiety concerning the stability of traditional cultural and political forms and relationships. Arguments for public schooling reflected this, as did emerging institutional arrangements, pedagogical practices, and curriculum content. Emile Durkheim, writing in support of a state system of education for example, contended that:

Education is ... the means by which society prepares, within the children, the essential means of its very existence ... Its object is to arouse in the child a certain number of physical, intellectual and moral states which are demanded of him by both the political society as a whole and the special milieu for which he is specifically destined. ${ }^{6}$

In the late $19^{\text {th }}$ century urban American school for example, the English language curriculum for immigrant children incorporated lessons in etiquette, dress, and grooming for the explicit purpose of fostering a consensus about how "normal" Americans and their families looked and acted. ${ }^{7}$ The answer to the question "what are you really?" was to be answered at school. Of course, as Jane Addams pointed out, young immigrants rarely had the resources that 
allowed them to dress or socialize according to these expectations. ${ }^{8}$ The effect, Addams feared, was to confirm rather than challenge immigrant children's feelings of marginality. School might produce young people who would accept the social logic that confined them to low-level jobs but who were now socially positioned outside and between a desired middle class culture as portrayed in school and the rejected old world culture of their parents. Addams understood, as many of her contemporaries did not, that school could foster alienation and loss.

The formal educational arrangements western industrialized states have inherited from that time are still intended to make children students of the dominant culture. By normalizing a dominant ideological perspective, schooling functions to conceal and repress alternative and dissenting perspectives. As socializing agents, schools classify, transmit, evaluate, and make coherent a partisan version of what knowledge is most worth. They have an explicit warrant to define, codify, and teach the terms in which individuals, their world, and their interactions will have social significance.

Michel Foucault insists that a society's need to normalize and regulate the identities of its members does not exist in the absence of resistance. ${ }^{9}$ Normalizing institutions emerge from within a network of specific historical circumstances that call for a formal means of control. Disciplinary institutions such as prisons, asylums, and schools represent relations of power that are connected to and in some sense sustained by wider social practices and beliefs. To maintain the continuity of those practices and beliefs, disciplinary institutions are granted power and authority over potentially noncompliant segments of society: criminals, the insane, and children. In the disciplinary institution's struggle to maintain its equilibrium in the face of shifts and recirculations in power, a discourse evolves that functions to define expressions of resistance as deviant and pathological. Discourse, as Foucault defines it, refers not simply to written and oral forms of communication, but to a whole network of shared meanings, ways of behaving and modes of expression within a historically determined community. The discourse that is constructed in institutionalized relations authorizes and sustains an understanding of the "normal." According to Foucault,

[I]t introduces the constraint of a conformity that must be achieved . . . [and] traces ... the external frontier of the abnormal. The perpetual penalty that transverses all points and supervises every instant in the disciplinary institution compares, differentiates, hierarchizes, homogenizes, excludes. In short, it normalizes. ${ }^{10}$

The process of normalization does not simply involve learning a situated language that one can then freely choose to use or not use. It also entails internalizing a dominant perspective and its logic of comparison. The institution cannot regulate identities unless it can establish boundaries that mark off difference. Those boundaries are encoded within the particular discursive practices learned within the institution. As the institution's inhabitants participate in and use its discourse, they are forced to look at the world and define relationships within it from a "normal" perspective that classifies and names the compliant and the deviant. The regulating power of normalization then, is that it lays claim to consciousness as well as behavior. As children receive their education in schools, they learn, as Virginia Woolf claimed she had not, a "standard of comparison" that enables them to define themselves within a context of others. 
Normalization at school may hold the promise of success in the public world, but it also signifies loss. Echoing the nineteenth-century immigrant children Jane Addams wrote about, Valerie Walkerdine describes how her education in post-World War II Britain removed her from the working class. In becoming middle class, she feels "split, fragmented and cut off." She writes, "I felt, in the old place, as in the new, that if I opened my mouth it would be to say the wrong thing. Yet, I desired so much, so very much, to produce utterances which, if said in one context, would not lead to rejection in the other." ${ }^{\prime 1}$ In his educational autobiography, The Hunger of Memory, Richard Rodriguez, a Spanish-speaking child in an English-speaking school in the America of the 1950s, recalls his debut as a compliant public self. "One day in school I raised my hand to volunteer an answer. I spoke out in a loud voice. And I did not think it remarkable when the entire class understood . . . At last, seven years old, I came to believe what had been technically true since my birth. I was an American citizen."12

Rodriguez's acceptance of his citizenship is not made possible merely because of a new facility in English. Like Walkerdine, he has begun to realize that a separation of home and school contexts must be observed if he is to succeed. Rodriguez has learned a situated language that is part of a larger discourse particular to his school. He now knows that if he is to participate he will have to repress his family's more intimate forms of expression and association that marks him off as different. He knows that he must signal his intention to speak by raising his hand, must wait to be recognized by the teacher, must talk in turn, can expect to be listened to by his fellow citizens, and will have the value of his contribution assessed by his teacher. With the use of each gesture he signals comprehension of, and compliance with, a new logic of social relation.

Schooling, of course, is not the first or only occasion in which individuals learn to define themselves in comparison to others. Comparison, differentiation, and classification appear to be central components in the earliest forms of human communication, and are foundational to all discourses. Participating within a particular discursive community, an individual learns how to situate and represent self and others. From a social constructivist perspective, personal identity is necessarily correlative and interdependent with the acquisition of the language of a group.

In George Herbert Mead's reconstruction of the process, a social "world that is there" prefigures the development of the "self conscious individuals" who interact and communicate within it. ${ }^{13}$ Human interaction and communication emerge from within that world as individuals learn how to anticipate the way their own actions or words will be understood by others. That is, if individual actors or speakers are to communicate successfully they must begin to put themselves in the other's shoes and view their own expressive behaviors from the imagined vantage point of the other. Thus for Mead, the self is a social construction. One's understanding and acceptance of a personal identity emerges in the dialogical interaction of self and other within a situational context.

Mead's favorite example was a baseball game. ${ }^{14}$ To play the game, one has to be able to see one's role within it from at least nine other players' positions and anticipate how they will respond. However, individual players not only see themselves as particular others do; they also interpret their own actions and beliefs form the historically-derived and socially-constructed perspective of a "generalized other" that defines the very nature of the game, its rules, standards, and ideals. Learning to communicate within a particular universe of discourse gives people the troubling gift of seeing themselves as others see them, or at least as they imagine they are seen. Discourses learned in school enable individuals to define a contextualized personal identity in a 
sphere more public than the family. This is what Walkerdine and Rodriguez tell us they are able to do because they attended school, and what Woolf tells us she is hampered in doing because she did not.

Foucault has argued that personal identity is a function of discourse and a way of positioning individual human beings as sites within larger relations of power; that the distinction between self and other is merely a useful convention and fiction. ${ }^{15}$ Mead did not question that fiction explicitly in his most widely-read work, Mind, Self and Society. As a result, his social psychology has sometimes been seen as naively naturalizing a dichotomy between self and other. ${ }^{16}$ This interpretation overlooks Mead's consistent and emphatic insistence on locating self and other as "standpoints" within a social "world that is there." Mead does not look for, or attempt to explain, configurations and shifts of power within this world. What he does explore is the way individuals take up particular positions and acquire an understanding of who they are within a larger social context. In effect, Mead's treatment of human sociality provides a framework for understanding how individuals collude in their own regulation.

The stories autobiographers tell about their early schooling are stories that deal with normalization and resistance. In their personal narratives, autobiographers reread their educational experiences and reconstruct their struggles to accommodate the generalized other as represented in the school's discourse of regulation and control. Their intent is to reappropriate a preinstitutional language and represent the school experience in the authentic voice of a "natural" preinstitutional self. Clearly, if the self is a social construction, these intentions can never be fully realized. But an autobiographer's struggle to recapture the as-yet-unregulated child's perspective and situation can help us to understand normalization from the inside.

\section{AUTOBIOGRAPHICAL DISCOURSE}

The self-absorption that seems to be the impetus and embarrassment of autobiography turns into a hunger for the world. Actually, it begins with a hunger for a world, one gone or lost, effaced by time or a more sudden brutality. But in the act of remembering, the personal environment expands, resonates beyond itself, beyond its "subject," into the endless tragic recollection that is history. ${ }^{18}$ Virginia Hampl

During a period of critical transition in the social sciences, the nineteenth century German philosopher Wilhelm Dithey advocated the study of autobiography as a means of understanding the cultural significance of lived experience. He contended,

Autobiography is the highest and most instructive form in which the understanding of life confronts us. Here is the outward phenomenal course of a life which forms the basis for understanding what has produced it within a certain environment. ${ }^{19}$

Dilthey understood life history as a "germinal cell" in which "the discreet is linked to continuity." In autobiography, he believed, "the self grasps the course of its own life in such a way as to bring to consciousness the historical basis of human life, namely the historical relations in which it is interwoven." 20 For Dilthey, while autobiographical interpretations of a life and its surroundings are admittedly personal and partisan, they offer historians and social scientists a "sympathetic insight" that is a more valuable form of documentation than a purportedly valueneutral organization of the facts. 
Dilthey's inquiries centered on a consideration of the bios, or life story, presented in autobiography. By examining a life story, Dilthey thought that the cultural scholar would have access to specific categories and themes as well as "the motives producing them" that characterized social relationships within particular historical periods. ${ }^{21}$ While in his writing he tended to place considerable confidence in the credibility of the autobiographer's assessment of those categories and themes, his followers, particularly George Misch, used autobiographical method in a much more restricted sense. ${ }^{22}$ Defining autobiography as a biography told in in the first person, their interest was to study great men who were somehow emblematic of their time; figures who could be considered experts and could tell the real story of the positive march of history.

Contemporary scholars of autobiography have been much more critical of the autobiographical perspective. They tend to focus on the autos, or self, and the graphia, or act of writing, that are embedded within the genre. Albert E. Stone, for example, concentrates on the figure of the self as presented in autobiographical writing. ${ }^{23} \mathrm{He}$ contends that the early proponents of autobiographical method were too sanguine about the reliability of the narrator of a life. He asks why we should trust narrators of memory and argues that autobiographical accounts have tended to derive more from an awareness of personal continuity, or self, than from an awareness of the cultural continuities of a historical epoch. His point is that autobiographies have more reliable things to say about selves than about history and culture.

As Sidonie Smith has recognized, the shift of critical interest from bios to autos does not resolve the problems of reliability in autobiography. ${ }^{24}$ Whether autobiography is defined primarily a life history told in the first person or as a re-creation of a self, its construction involves the use of memory and imagination. Virginia Woolf recognized this problem in her "Sketch of the Past" and questioned whether any autobiographer could rely on memory to supply the most significant details of one's past. In her own experiments with memory she asks, "Why have I forgotten so many things that must have been, one would have thought, more memorable than what I do remember? Why remember the hum of bees in the garden going down to the beach, and forget completely being thrown naked by father into the sea?"25 Like Woolf, Patricia Hampl observes in her autobiography that what one recalls is "selective, subjective, cannily defensive, unreliable as fact." ${ }^{26}$ However, she contends that, "the imprecision of memory causes us to create, to extend remembrance into narrative." That narrative for Hampl is "not just private and not just memory" but an interpretive connection of past and present that has a more compelling claim to accuracy than mere fact. ${ }^{27}$ The proper question, then, may not be how fully an autobiographer remembers "the life" and reliably reports it, but rather how convincingly she or he has used the fragments of memory to tell a meaningful and coherent story. ${ }^{28}$

A focus on the autos rather than bios within autobiography that Stone and others suggest, however, has its own interpretative challenges. In an autobiography, an authorial self, or narrator, reinvents a historical self, or protagonist. The "I" of the narrative is thus both the subject and object of the text. In recreating the self, the autobiographer selects and edits the life. He or she presents only those experiences, thoughts, and details that explain identity from the perspective of the narrator situated in the present. How then can an account of a self be true in the conventional sense of the term? How real is its depiction? And what self do readers of the text see as authentic: the historical self of the past living its life in the text, or the narrating authorial self of the present writing about the past life in the present? 
Again, Woolf saw these difficulties. In trying to portray accurately her childhood feelings for her mother, she comments that "if the things that ceased in childhood are easy to describe because they are complete, then it should be easy to say what I felt for my mother." ${ }^{29}$ It isn't easy because her experiences as an adult authorial self - "all those descriptions and anecdotes which after she was dead imposed themselves on my view of her"- - keep getting in the way of her recovery of her historical self's childhood feelings. ${ }^{30}$ There is an interplay of several selves here, all belonging to Woolf at different periods of her life, all having distinctive perspectives, all in some way related, but all incomplete. Further, Woolf admits that "What I write today I should not write in a year's time." ${ }^{11}$ Even the self who assumes the position of narrator shifts and changes over time.

Woolf's meditation on her inability to complete an autobiography raises serious doubts about whether there is one authentic self that can be represented within a text and points to the need to reframe the questions of accuracy scholars of autobiography have raised concerning autobiographical self-representation. What seems to matter most is not which of the selves presented are more real or true, but how their discontinuities are understood and framed by an author writing within a particular present.

The problematics involved in autobiography get more complex when we direct our attention to the graphia or the act of writing that creates discourse between a writer and reader of the text. Elizabeth W. Bruss maintains that the author of an autobiography rereads a life as she or he rewrites it. ${ }^{32}$ The process, according to Bruss, involves an attempt to reclaim and use a lost language of a "truer" self and make it comprehensible to others. Autobiographers thus have to reposition themselves in the perspective of an imagined reader and construct a shared contextual ground in which the self's thoughts and actions will be read sympathetically. As Steedman observes, "the point . . . is to make an audience connive in the telling." 33 In an important sense, the imagined community of readers functions as a writer's generalized other. The effort is intended to unite the authorial self, or first reader of the life, to the text's subsequent readers as a "we." "We," an autobiographer wants to be able to say, "can look back at this life in this way."

Autobiographers attempt to transform available discourse so that past and present can be redefined and connected through the voice of the narrator. The words and images they choose to use are intended to create a web of significance that clarifies their earlier thoughts and actions. Thus the ordering experience in autobiography is necessarily different from a purely historical chronology. The language used to construct the text must carry the reader back and forth through time and place as the author's past experiences as well as present perspective are divulged. The story is told, narrative choices are made, with a reader in mind. If the portrait of the self is to be read sympathetically, it will need to be presented in conventions of expression that its reader will recognize.

The resources available to create an autobiographical narrative include a life that must be reread and edited by its author, a cultural context and historical space in which a life can be situated, and at least two languages: a language of the past spoken by a purportedly true or natural self, and a language of the present spoken by a culturally literate authorial self. Although the deployment of these resources is certainly complex, the problem of the critic who attends to the act of writing is not merely one of complexity. It is also the extent to which any autobiographer can avoid or resist framing his or her self and life in the wordings and logic of a dominant culture. 
As one turns to the graphia in autobiography, the questions that emerge return us to Dilthey. For despite the emphasis his followers placed on tracing the course of the life of the exemplary man, Dilthey himself wanted scholars to be particularly attentive to the way an author creates the context in which a life makes some sort of sense. However selective or misdirective the presentation of self, or however determined the use of available discourse, the significance of personal narrative for Dilthey was that it recreates a self in its world. This is accomplished in the act of writing. As Stone suggests, autobiographers are like anthropologists returning to their own pasts. The reconstruction of the world a self has inhabited in the past necessarily involves the autobiographer in cultural analysis and critique. Thus while autobiographies may appear to focus on identity, they inevitably deal with questions of time and place as well. They must be able to understand and convincingly portray in writing a world in which a self and life belong.

\section{THE NARRATIVE FRAMING OF SCHOOLING}

I never learned hate at home, or shame. I had to go to school for that. ${ }^{34}$ Dick Gregory

The critical challenges I have briefly outlined are mediated by autobiographers as they develop discursive strategies in the construction of their texts. Particular autobiographical occasions call for the use of thematic sequences and frames that will be coherent to the reader. The particular autobiographical occasion explored here is a child's confrontation with the regulating powers of a literate culture in school. In my discussion I have intentionally selected autobiographical passages from authors who speak from a diversity of individual perspectives, who attended a variety of different schools, and who have written about a variety of times, place, and personal events. But while they speak from the particularities of their own lives, these authors structure and plot their narratives of early schooling in terms that seem to apply across their differences. As they grow older in their texts and begin to resolve the problem of identity, the resemblances of story give way to a particularization and specificity of voice. But here, in a reimagined childhood, the contours of the plot emerge as commonalities.

In educational autobiographies the individual's experience of institutional normalization at school is organized as a story of disruption and loss. Children leave home and must relinquish ties to a primary language and culture in which they knew who they were and where they belonged. In some cases the educational autobiography becomes a fondly remembered and nostalgic celebration of this transition that can be integrated with the adult author's larger sense of personal identity. ${ }^{35}$ More often, however, educational autobiographers depict the disruption as a violation they have been forced to accommodate. Emerging from their schooling as literate social selves, they attempt to recover the voice of a lost child. The construction of the autobiography becomes an attempt to displace the school's and its teacher's powers as formative agents of the self. The narrator can then symbolically resist the psychological violence of schooling, restore imagined ties to a lost culture, and become the 'true' author of the educated self.

In When the Grass was Taller: Autobiography and the Experience of Childhood, Richard Coe contends that autobiographical representations of childhood have an unusually sharp and perceptually focused character. ${ }^{36}$ The child sees, smells and hears with an acuteness lost in adult experience but with none of the adult's resources for understanding. The earliest reminiscences of school confirm Coe's observation. They center on a perceived strangeness and are retold as a terrifying entry into an alien culture presided over by towering adults who speak an incomprehensible language and expect their charges to act in incomprehensible ways. The 
presence of the place is often evoked through meticulously sensuous detail, now familiar but distant, then strange but near.

George Orwell recalls his early days as an eight-year-old at an English boarding school in 1911 by describing "The inky, dusty smell of the big schoolroom, the rosiny smell of the chapel, the stagnant smell of the swimming bath and the cold reek of the lavoratories." He remembers looking up at adult faces and the way he experienced "the enormous size of grown ups, their ungainly, rigid bodies, their course wrinkled skins, their great relaxed eyelids, their yellow teeth, and the whiffs of musty clothes and beer and sweat and tobacco that disengaged from them every moment." 37 Rodriguez remembers the sounds of a strange language: "exotic polysyllabic sounds would bloom in the midst of their sentences . . . [a]s chirping clatter above me."38 Kate Douglas Wiggin, after reconstructing the Maine landscape of her one-room New England school district in the 1860 's with some affection, recalls being surprised by the "large windows," "ugly stove," "battered, scarred, cut and stained desks," and "long low bench," and vividly remembers that she directed her gaze downward at the "white stockings and ankle ties" of the other children who were seated near her. ${ }^{39}$ Zitkala-Sa, a student in an Indian boarding school in the American Midwest during the 1880 s, remembers,

The strong glaring light in the large white-washed room dazzled my eyes. The noisy hurrying of hard shoes on bare floors increased the whirring in my ears ... A rosy checked pale faced woman caught me in her arms ... We were taken along an upward incline of wooden boxes which I learned afterward to call a stairway. $^{40}$

In each of these widely divergent cases, a sense of strangeness is created out of a context of familiarity. Readers who have been students, or have access to what it means to have been a student, understand the imagery of rosiny and inky smells, carvings on desks, and gigantic adults speaking a strange tongue above them. They share with the writer a memory of what was at first inexplicably odd and now makes perfect sense. Each autobiographer has used common referents derived from school experience to evoke recognition and sympathy. She or he has in fact used what was learned in school to point out the school's absurdity.

These educational autobiographers present the student protagonist as caught between an imaginatively conceived private culture and the absurd but powerful public culture of the school. Rodriguez explicitly asserts, "Education is a long, unglamorous, even demeaning process; a nurturing never natural to the person one was before one entered the classroom." 41 The problem for the historical self or protagonist within the text is how to respond to the lessons of school. Will the child comply or resist? The problem for the authorial self is how to establish a narrative context in which to rewrite actual acts of defiance and accommodation so that readers can become allies of the remembered child.

In Wiggin's story, she describes how her "extreme gayety, desire to look out of windows [and] tendency to mirth" were met with humiliating punishments. ${ }^{42}$ Made to sit beneath her teacher's desk, Wiggin pretends to comply docilely. Yet she tells her readers that, once hidden from view, she threw her skirts over her head and secretly recited the much loved poems she had learned at home. While the tone of this narrative is humorous, it has the effect of showing how Wiggin subverted her teacher's authority and affirmed emotional associations to her private life within her family. Her teacher and classmates could not have known of her small acts of 
resistance that would have evoked further and more serious punishment. But she and her readers can look back at the small child's efforts with amusement rather than censure and take the side of the child.

Orwell also contrasts his life at home and school, but, unlike Wiggin, finds no place to hide from observational control within the school context. The power of the institution to supervise and define his behavior is filtered through and among not only his teachers but his fellow students as well. Within the text he creates an explanatory framework in which uncomprehending and malleable children are simply unable to act on their own behalf:

My own main trouble was an utter lack of a sense of proportion of probability. This led me to accept outrages and believe absurdities . . . Of course my case had its individual variations, but essentially it was that of countless other boys. The weakness of the child is that it starts with a blank sheet. It neither understands or questions the society in which it lives, and because of its credulity other people can work upon it infecting it with the sense of inferiority and dread of offending against mysterious, terrible laws. ${ }^{43}$

Students, however, come to act as if they understand those "mysterious and terrible laws." They attempt, as Wiggins did, to appear to listen while they hide their defiance or, as Rodriguez did, to listen and concur with what is being said concerning who they are and where they fit in within the school's culture. Having listened, Rodriguez can come to identify himself first as a citizen and later, as he begins to gain facility in the school's discourse, as a "scholarship boy"; a remarkably good student who the system defines as culturally disadvantaged and whose academic success remains an anomaly. However, having been forced to listen and acquiesce to the school's discourse in the past, educational autobiographers can shift the balance of power in their written stories. Orwell, as the author of his own education, for example, can now resist by reorganizing his weakness and credulity as a boy to point out the outrages he experienced in the past.

Like Orwell, Maya Angelou resists in writing what she appeared to accept in her actual past experience as a student in the American South during the late 1930s. Recreating a racist white school administrator's speech in her segregated elementary school graduation ceremony, she can finally express her outrage.

It was awful to be a Negro and have no control over my life . . . I thought I should like to see us all dead, one on top of the other. A pyramid of flesh with the white folks on the bottom, as the broad base, then the Indians with their silly tomahawks and teepees and wigwams and treaties, the Negroes with their mops and recipes and cotton sacks and spirituals sticking out of their mouths. The Dutch children should all stumble in their wooden shoes and break their necks. The French should choke to death on the Louisiana Purchase (1803) while silkworms ate all the Chinese and their stupid pigtails. ${ }^{44}$

As autobiographer, Angelou reappropriates the curricular discourse of the schoolroom and transforms it into a critique. Her use of valued school knowledge, with its accepted imagery, 
proves that she understands the language of her school and can pass its tests if she wishes. In her story she is reimagined and represented as a good student who deserves to be designated a graduate. From her present perspective, she shows that she knows how to satirize the school curriculum she has mastered with devastating irony and force.

As the narrator of her life, Angelou has seized the right to define who she was and how she felt as a student. She reveals her real but hidden perspective as she stood immobilized at her graduation. And, in her authorial voice, she traces the outlines of what an educated person in American society should be. It is not that she knows the date of the Louisiana Purchase or who belongs to tomahawks, spirituals, wooden shoes, and silkworms that allows her to locate herself within the narrative as an educated person. Rather, her rejection of the racist stereotypes that trivialize human diversity becomes central to the image she constructs of the educated person.

Unlike Orwell or Angelou, Zitkala-Sa recounts a more overt resistance in her educational autobiography. The most compelling episode involves having her long hair shingled by her white teachers. First she provides a common interpretative context by calling up values that can be understood across cultures. She writes, "Our mothers had taught us that only unskilled warriors who were captured had their hair shingled by the enemy. Among our people, short hair was worn by mourners, and shingled hair by cowards." 45 The nature of the outrage established, she then reconstructs her efforts to resist: "On my hands and knees I crawled under the bed, and cuddled myself in the dark corner ... I remember being dragged out, though I resisted by kicking an scratching wildly. In spite of myself, I was carried down stairs and tied fast in a chair."46

Zitkala-Sa's use of the phrase "in spite of myself" is an affirmation in the present of her unsuccessful efforts to resist in the past. As opposed to the person the institution required her to be - a compliant school girl, rather than a savage - the person she imagines as her authentic self would have remained in braids and not assumed the appearance she understood as that of a coward, incompetent, enemy, or mourner. While as a student she was in fact coerced into becoming all of these things within the controlling discourse practiced at school, her authorial self can reframe the ineffectual actions of the child as courageous and exemplary: "I cried aloud, shaking my head all the while until I felt the cold blades of the scissors against my neck and heard them gnaw off one of my thick braids. Then I lost my spirit." ${ }^{27}$ With the loss of spirit, Zitkala-Sa begins outwardly to accept and accommodate what she can now interpret as the "chains that tightly bound my individuality." She writes "[A]s it was inbred in me to suffer in silence rather than to appeal to the ears of one whose open eyes could not see my pain, I have many times trudged in the day's harness heavy footed like a dumb sick brute." ${ }^{48}$

As readers begin to see these children's experiences from the inside and share with their autobiographers a discovery of the thoughts and feelings that have been repressed and concealed, they are drawn to assume the autobiographer's perspective. They come to know more about what was "really going on" than did the historical figures of teachers and classmates who surrounded the child in the past, "whose open eyes could not see...the pain."

In authoring one's own life, autobiographers challenge the irrevocability of the past. In effect, they reach back across time and say those things that remained unsaid, transform failure into success, and make achievements of humiliations. They can also finally win arguments. In My Garden of Memory, Wiggin describes an incident in her adult life following the publication of her work on early childhood education. ${ }^{49}$ She meets the teacher who had placed her under the 
desk and, not surprisingly, has the last pedagogical word. Wiggin organizes the conversation in the text to successfully reject and critique the methods of her former school teacher and indirectly advance her own. Yet the scene seems contrived; too good to be true. Somehow that doesn't really seem to matter, however, for the story functions as a truthful critique. As a skilled story-teller, Wiggin has drawn her readers into her discursive resistance. Even if they doubt her veracity as to the facts, her readers are positioned to become complicit. They respond as if the story she has constructed is an accurate portrayal of the assumptions implicit in coercive school practices. Wiggin the narrator, the experienced kindergarten teacher, the successful write of children's stories, and the advocate of "imaginative play," constructs a situation infused with her present stature and personality that encompasses images of her distant and recent pasts. She is firmly in control as she makes her mature philosophy of education clear and connects her childhood experiences to her adult career and commitments. But the construction of the continuity of self that Wiggin achieved is only possible from the vantage point of adulthood.

As Coe maintains, children occupy a space in autobiographical narratives in which "the former self-as-child is as alien to the adult writer as to the adult reader." $50 \mathrm{He}$ argues that the distance between an autobiographer and his or her self diminishes as the life unfolds in the text. If this is the case, then an explication of one's childhood requires both a more creative use of interpretive strategies and a closer reading of the situational context than does an explication of adulthood. In educational autobiography this places the author as well as the reader of the lost child's experiences in the position of newcomers to the phenomena of schooling. School is still seen as a problem requiring critical description and reflective reconstruction.

An autobiographer may approach his or her task as one of a search for a lost child who existed in the historical past and see that child, as Coe argues, as alien and separate. The narrative functions, however, to bring the remembered and imagined child forward in time and associate it with its author. As Virginia Woolf knew, it is impossible for an author of a life to leave behind the symbolic equipment that has been learned in living that life up to the period of narration. One does not return to the past to rescue one's child-self and articulate a lost voice unencumbered with the suppositions that have developed within a larger social context. The positing of an authentic child by an autobiographer thus has to be approached skeptically. While, as Coe points out, detailed memories from childhood may be vibrantly clear, their import is only explicable from an adult's perspective.

"Why remember the hum of bees?" Woolf asks. Clearly, were it possible to ask the three-year-old Virginia Stephen, as she heard those bees on the coast of Cornwall in the summer of 1885, what they signified, we would receive a very different explanation from the one that the fifty-seven-year-old author Virginia Woolf might have given had she chosen to interpret the memory within an autobiography. In fact, the "real" historically-situated child's explanation, disconnected from the interpretation in the present, would not be of much use to an understanding of Woolf as an adult. As Steedman writes,

In childhood only the surroundings show, and nothing is explained. Children do not possess a social analysis of what is happening to them, or around them, so the landscape and the pictures it presents have to remain a background, taking on meaning later, from different circumstances. ${ }^{51}$ 
In educational autobiography, one of the objects of critique is the legitimacy of the society's rights to an individual's consciousness through schooling. This challenges a foundational assumption embedded within traditional treatises on formal education, where education at school has been assumed to be a positive and effective way of controlling individuals in the interests of larger social imperatives. Ideally, schooling makes the compulsion to conform to those imperatives invisible. It "binds together the reproduction of skills and the ${ }_{53}$ reproduction of consciousness and develops in each individual an acceptance of his or her role."

Autobiographers who tell the stories of their early schooling offer a description of the school context that makes the organization of its reproductive powers visible and discloses the points at which particular individuals have refused to accept the roles and identities assigned them in the school's discourse. Because of the demands of the genre, their stories describe what Woolf might have called the stream of normalization as well as the children caught within it. And, in looking back to depict that stream through a child's perspective, they discover moments when a school's regulating powers might be susceptible to acts of subversion and transformation.

What seems evident from my reading of educational autobiographies is that early normalization at school is experienced as remarkable similar by children, despite significant differences in the adult voices of the authors who reconstruct, interpret, and act against it in their writing. I do not want to make the case that children, despite differences in class, race, gender, nationality, or historical era, respond to their schooling in the same way or that their stories have the same endings. Rather, I want to argue that educational autobiographers, as they look back at school experience, confront similarities in the configuration of power within what Zitkala-Sa called "the iron routine of the great civilizing machine." ${ }^{54}$ The social contour of the machine, not the children or their story tellers, is what accounts for the commonalities of plot and positioning of protagonists in autobiographies of early school experience.

The plot of the educational autobiography involves a child who leaves home for school to come face to face with an alien culture. As the child is coerced into becoming a student of the culture, she or he is expected to conform, to hear and internalize the perspective of the generalized other, and to define himself or herself as a member. Bafflement, wonder, and tacit or overt resistances are gradually transformed into outward compliance. For Rodriguez compliance is represented as conscious and voluntary; the only "smart" thing to do given the inevitability of the school's control. For Orwell it was the result of fear and powerlessness. In Zitkala-Sa's case, compliance became a lonely passive resistance.

Accommodations to the school's regulation are explained by autobiographers as strategies for survival. They allow the child in the text to harbor and cherish what their autobiographers represent as a well-concealed authentic private self. Wiggin relates how she created a private space for that self under her teacher's desk. Angelou, finding that she is "constrained by hard-learned manners" to sit listening, draws into that self by "silently rebutting each sentence with my eyes closed." " 55 Orwell writes that during his mistreatment at school he had the feeling that "all the while at the middle of one's heart, there seemed to stand an incorruptible inner self." 56 The reimagined child's feelings and thoughts are finally given expression. The child who could not speak has been given a voice. The student has lived to tell the tale, and by telling it, symbolically transforms and overthrows the school's control. While the child-self in the text must be understood as a fiction, it is a fiction both a reader a writer of 
autobiography accept. It allows a writer to describe and a reader to understand both the relations of power experienced at school and what the autobiographer has discovered as significant in his or her own development as an educated person.

As we have seen, the autobiographer's effort to become the author of the educated self is fraught with discursive difficulty. Autobiographers are obliged to develop strategies to join memory and analysis; move between and connect times, places and perspectives; anticipate their readers' response; and construct a story in which the private self speaks in a credible voice. Ironically, the formal educational experience of the individual provides the symbolic ground that makes an authorial rereading and rewriting of the author's education possible. The tale is told and the private self is given expression in its writer's second and more literate public language. It is derived from the discourse that has been learned in school.

Although educational autobiographies are plotted as stories of resistance, they are connected to and limited by a normalization that cannot ever be fully displaced. This does not weaken the value of the autobiographical act as cultural critique. Rather, the discursive problems an autobiographer confronts initiate a unique interpretation of the relations between subject, self, author, and world that other more scholarly interpretations lack. As Janet Gunn argues,

Autobiography is not an escape from time but a plunge into it; not as a self's divestment of its world-involvement, but as an acknowledgement of its temporal experience. The autobiographical impulse exhibits the most basic level at which we live as human agents, in a certain situation and always in relation to certain assumed meanings we know as culture. ${ }^{57}$

Contemporary critical scholarship in educational studies has questioned the legitimacy of the school's traditional warrant to regulate individual identities and pointed to the coercive and partisan nature of its socialization practices. Within this context, personal narratives have begun to be seen as an important source of documentary evidence and as a distinct mode of inquiry. The contributions of personal narrative to new ways of seeing are now being explored on a number of fronts in educational studies. ${ }^{58}$ Students,' teachers,' and researchers' stories, told in their own voices, have been given a new place and authority. As I have attempted to illustrate here, the school stories recounted in published autobiographical works also have a contribution to make. A story is written or told to explain, to make sense of, some problematic event or experience. The value of educational autobiography is that it is a story that can tell us about an individual's inquiry into what it means to become an educated self. The stories that emerge from that act of inquiry can also help us understand the terrible and complex continuity of the school's power of normalization.

\section{Endnotes}

1. Virginia Woolf, Moments of Being (London: Grafton Books, 1989), 73-74.

2. For a discussion of forms of autobiography and educational biography see: Philippe Lejeune, On Autobiography (Minneapolis: University of Minnesota Press, 1989); Peter Abbs, A is for 
Aesthetic: Essays on Creative and Aesthetic Education (London: The Falmer Press, 1989); James Olney, ed., Autobiography: Essays Theoretical and Critical (Princeton, N.J.: Princeton University Press, 1980); Shari Benstock, ed, The Private Self: Theory and Practice of Women's Autobiographical Writings (Chapel Hill: University of North Carolina, 1988).

3. Carolyn Steedman, Landscape for a Good Woman: A Story of Two Lives (London: Virago Press, 1986), 143.

4. Richard Coe, When the Grass was Taller: Autobiography and the Experience of Childhood (New Haven: Yale University Press, 1984).

5. Virginia Hampl, A Romantic Education (Boston: Houghton Mifflin Company, 1981), 27.

6. Emile Durkheim, Education and Sociology (New York: Free Press, 1956), 32.

7. English for Foreigners, A Teaching Guide (New York: Henry Holt, 1906).

8. Jane Addams, "Immigrants and Their Children," Twenty Years at Hull House (New York: New American Library, 1981), 169-85.

9. Michel Foucault, Discipline and Punish: The Birth of the Prison (New York: Vintage Books, 1977).

10. Ibid., 183.

11. Valerie Walkerdine, "Dreams From an Ordinary Childhood," Truth, Dare or Promise: Girls Growing up in the Fifties, ed. Liz Heron (London: Virago Press, 1985).

12. Richard Rodriquez, The Hunger of Memory: The Education of Richard Rodriguez (New York: Bantam Books, 1982), 22.

13. George Herbert Mead, Mind, Self and Society (Chicago: University of Chicago Press, 1972).

14. Ibid., 152-63, 174, 175.

15. Michel Foucault, The Care of the Self: The History of Sexuality, Volume 3 (New York: Random House, 1988). Foucault has argued that the concept of "author" is also a fiction that should be deconstructed in "What is an Author," Screen 1, no 1, 13-33.

16. Susan Douglas Franzosa, "Misreading the Meadian Texts," Vitae Scholasticae 8, no. 1 (Spring 1989): 141-70.

17. Mead, Mind, Self and Society, 186-9), The Philosophy of the Act (Chicago, University of Chicago Press, 1938), 45.

18. Hampl, Romantic Education, 4-5.

19. Wilhem Dilthey, Pattern and Meaning in History, ed. H. Rickman (New York: Harper and Row, 1960), 89. It is interesting to note that Mead, as Dilthey's student in Germany during the 1880s, knew the claims of the autobiographical method; Susan Douglas Franzosa, "The 
Emergence of the Pragmatic Attitude: An Educational Biography of George Herbert Mead," Vitae Scholasticae 3, no. 1 (Spring 1984): 33-60.

20. Dilthey, Pattern and Meaning, 111.

21. Wilhelm Dilthey, Selected Readings, ed H.A. Hodges (London: Kegan Paul, Trench, Trubner and Company Ltd, 1944), 12.

22. George Misch, A History of Autobiography in Antiquity (London: Routledge and Kegan Paul, 1950).

23. Albert E. Stone, Autobiographical Occasions and Original Acts (Philadelphia: University of Pennsylvania Press, 1982).

24. Sidonie Smith, A Poetics of Women's Autobiography: Marginality and the Fictions of SelfRepresentation (Bloomington: Indiana Press, 1987).

25. Woolf, Moments of being, 78 .

26. Hampl, Romantic Education, 5.

27. Ibid, 8.

28. Reconstructions of the past outside of autobiographical discourse are now generally acknowledged to be products of interpretive, creative, and selective process of interpretation within philosophy of history and social sciences: Hayden White, Tropics of Discourse (Baltimore, Md: Johns Hopkins University Press, 1978); David Carr, Time, Narrative and History (Bloomington: Indiana University Press, 1986); Donald Spence, Narrative Truth and Historical Truth (New York: Norton Books, 1984); Donald E. Polkinghome, Narrative Knowing and the Human Sciences (New York: SUNY Press, 1987). Carolyn Steedman's discussion of the implications of this critical transition are particularly useful in: "Biographical Questions, Fictions of the Self," Childhood, Culture and Class in Britain: Margaret McMillan 1860-1931 (London: Virago Press, 1990), 243-59.

29. Woolf, Moments of Being, 89.

30. Ibid, 92 .

31. Ibid, 84 .

32. Elizabeth W. Bruss, Autobiographical Acts: The Changing Situation of a Literary Genre (Baltimore: Johns Hopkins University Press, 1976).

33. Steedman, Landscape for a Good Woman, 22.

34. Dick Gregory, nigger: An Autobiography (New York: Dutton Press, 1964), 114.

35. Mary Antin's The Promised Land (Boston: Houghton Mifflin, 1912) is recognized as a memoir of this type. Chap. 5, "Schooling," in Jill Ker Conway's The Road From Corain (New York: Random House, 1989), 83-119, is a recent case. However, the fact that these or 
other authors eventually came to "like school" despite their first experiences of confusion and alienation, is not a counter example of the process discussed in this paper.

36. Coe, When the Grass was Taller, 99.

37. George Orwell, Such, Such Were the Joys (New York: Harcourt, Brace Jovanovich, 1953), 63.

38. Rodriguez, Hunger of Memory, 14.

39. Kate Douglas Wiggin, My Garden of Memory (Boston: Houghton Mifflin, 1923), 45.

40. Zitkala-Sa, American Indian Stories (Lincoln: University of Nebraska Press, 1979), 49-50.

41. Rodriguez, Hunger of Memory, 68.

42. Wiggin, Garden of Memory, 44.

43. Orwell, Such Were Joys, 62.

44. Maya Angelou, I Know Why the Caged Bird Sings (New York: Bantam Books, 1971), 153.

45. Zitkala-Sa, American Indian Stories, 55.

46. Ibid.

47. Ibid., 56.

48. Ibid., 66.

49. Wiggin, Garden of Memory, 44.

50. Coe, When the Grass was Taller, 2.

51. Steedman, Landscape for a Good Woman, 28.

52. Woolf, Moments of Being, 90.

53. Walter Feinberg, Understanding Education: Toward a Reconstruction of Educational Inquiry (New York: Cambridge University Press, 1983), 163.

54. Zitkala-Sa, American Indian Stories, 66.

55. Angelou, Caged Bird Sings, 154.

56. Orwell, Such Were Joys, 90.

57. Janet Varner Gunn, Autobiography: Toward a Poetics of Experience (Philadelphia: University of Philadelphia Press, 1982), 13.

58. Interest in narrative within educational studies originated as a way of reconceptualizing pedagogy and curriculum in Britain with Peter Abb's Autobiography in Education (London: Gryphon Press, 1974) and Reclamations (Lond: Heinemann, 1975) and in the United States 
with William Pinar and Madeline Grumet, Toward a Poor Curriculum (Dubuque, Iowa: Kendall Hunt, 1976). More recent works have explored narrative as a method of research as well as pedagogical technique: Deborah Britzman, Practice Makes Practice: A Critical Study of Learning to Teach (New York: SUNY Press, 1989); F. Michael Connelly and Jean Clandinin, Teachers as Curriculum Planners (New York: Teachers College Press, 1988); Ivor Goodson, Biography Identity and Schooling (London: Falmer Press, 1988); Carol Witherall and Nel Noddings, eds., Stories Lives Tell: Narrative and Dialogue in Education (New York: Teachers College Press, 1991); and William Schubert and William C. Ayers, eds., Teacher Lore: Learning From Our Own Experience (New York: Longman, 1991). 